\title{
Learning Strategies in Reading: The Case of Indonesian Language Education Student Teachers
}

\author{
Nazurty $^{1}$, Rustam $^{1}$, Priyanto $^{1}$, Nurullaningsih ${ }^{2}$, Anggia Pratiwi $^{3}$, Sarmandan $^{1}$, Akhmad Habibi $^{1}$, \\ Amirul Mukminin ${ }^{1, *}$ \\ ${ }^{1}$ The Graduate School, Universitas Jambi, Indonesia \\ ${ }^{2}$ Faculty of Teaching Training and Education, Tridinanti University, Indonesia \\ ${ }^{3}$ Sekolah Tinggi Keguruan dan Ilmu Pendidikan-YPM, Indonesia
}

Received August 15, 2019; Revised October 21, 2019; Accepted October 28, 2019

\begin{abstract}
Copyright $\bigcirc 2019$ by authors, all rights reserved. Authors agree that this article remains permanently open access under
\end{abstract} the terms of the Creative Commons Attribution License 4.0 International License

\begin{abstract}
This study aimed at analyzing the English reading strategies used by Indonesian language education student teachers at an Indonesian public university, particularly the types and frequencies of English reading strategies that the student teachers used. The participants of this study were student teachers from one language study program. The study involved 570 student teachers, 438 females and 132 males. This study used a quantitative design with a survey approach. This study utilized a questionnaire consisting of 23 items. Reading strategies (cognitive and metacognitive) were evaluated under three headings: pre-reading, while-reading, and post-reading. The results of this study indicated that the most strategies used by students in pre-reading, while-reading, and post-reading were cognitive strategies. Hence, the students in this study categorized as the cognitive reading strategy users. The gender-based analysis of the reading strategies category revealed that female students were cognitive users, while male students were metacognitive strategies users. The implications of the findings are also discussed.
\end{abstract}

Keywords Effective Literacy Practices, Reading Strategies, Reading Comprehension

\section{Introduction}

Teachers in Indonesia meet a serious situation as numerous foreign language learners are struggling to read well (OECD, 2015). This situation should be taking into consideration because reading is an important and critical skill for students to achieve educational success. Recent research on reading subject has shown that reading exists as a complex cognitive activity crucial to gain information in contemporary society for sufficient function. Hence, the ability to read well is a crucial asset for students, as they have to manage a certain academic achievement level (Alfassi, 2004; Brown. 2007; Nordin, Rashid, Zubir, \& Sadjirin, 2012). English as a compulsory course in Indonesian universities has become a main foreign language that higher education students should focus on (Abrar et al., 2018; Husarida \& Dollete, 2019; Makmur et al., 2016; Marzulina et al., 2019; Mukminin et al., 2015; Mukminin et al., 2018). Regarding reading comprehension in English courses, students have many challenges to comprehend reading texts such as understanding the meaning of texts and the structure of sentences. Therefore, reading strategies are important for Indonesian students learning English.

The way to get the reading comprehension in English is that the students should "Understand the meaning of text, critically evaluate the message, remember the content, and apply the new-found knowledge flexibly" (Alfassi, 2004. p. 171). Zhang and Seepho (2013) and Zare (2010) argued that if the language learners' use reading strategies appropriately and frequently, it will be helpful for the non-native readers because it can be served as an effective way to overcome language proficiency and to gain reading achievement better on language proficiency test. The research on reading strategies should be always carried out due to the rapid change of the ways students learn in the $21^{\text {st }}$ century education. Therefore, this study was conducted to answer two guiding questions regarding reading comprehension in an English course for Indonesian language student teachers.

1. What are the common strategies of English reading used by Indonesian language student teachers?

2. What are the differences of reading strategies used by female and male students? 


\section{Literature Review}

Regarding learning strategies, O'Malley, Chamot, Stewner - Manzanares, Kupper, and Russo (1985) and Oxford $(2003,1989)$ had revealed their learning categories. O'Malley et al., (1985) divided learning strategies into six types, they are: memory strategies referring to the way of students to manage their ways in learning. Second, cognitive strategies refer to the way of students to determine the limitations of knowledge. Third, metacognitive strategies refer to the way of students to manage their ways in learning. Fourth, compensation strategies refer to the way of students to determine the limitation of knowledge. Fifth, affective strategies refer to strategies that relate to students' feelings. The last, social strategies refer to the way of students in learning by involving the others. Oxford (2003) divided learning strategies in reading into direct and indirect strategies. Direct strategies are divided into some strategies; they are memory strategies in which the students use their memory in learning to remember about materials that they have learnt, while cognitive strategies focus on the students who use their knowledge in learning by repeating, analyzing, and summarizing. In terms of compensation strategies, students use them when they have insufficient knowledge such as guessing meaning. Indirect strategies are also divided into metacognitive, affective, and social strategies. For the metacognitive strategies, students do some aspects in acquiring the target language such as arranging the planning in learning, and evaluating the result of learning. For the affective strategies, students' feelings such as anxiety, emotional temperature, attitude and motivation are involved. In terms of social strategies, students involve their environment or others, such as asking question and cooperating with others.

Some language experts (Bezci, 1998; Noli \& Sabariah, 2011; Ozek \& Civilek, 2006; Salataci, 2002; Saricoban, 2002) divided reading activities into three stages: pre-reading, while-reading and post-reading: Pre-reading begins constructing meaning from context and this stage activity assists students to activate what they know about a topic and guess what they will read (Saricoban, 2002). In this stage, the readers will plan the strategies that will be used in reading text in order to make the texts more accessible during the reading. At least, the aims this stage is the attention of students about the strategies that are used in while reading activity as the next stage. Furthermore, the strategies that are used in this stage are strategies that are related to activate their background knowledge and understanding what the text is mainly about, such as guessing the content of text based on the title or guessing the text about by pictures or illustration that display in the text (Bezci, 1998).

While-reading is the process that occurs in readers' mind that happens more than once, (Salataci, 2002). Furthermore, while-reading is the stage when the readers build their understanding of the text and become engaged in reading process by using appropriate strategies. In this stage, readers hope to know that when they use the appropriate strategies, they could contribute to their understanding. Students who know the good timing "how" and "when" to use certain reading strategies to make sure that they understand about what they are reading to be categorized as good or proficient readers (Oxford, 2003). Some strategies that can be applied in this stage such as checking for understanding, confirming predictions, asking questions and pausing. In addition, in this stage, bottom-up and top-down strategies can be applied such as background knowledge, prediction, getting the idea of a text, skimming, scanning, and many others (Ozek \& Civilek, 2006).

Post-reading is the stage as important as those pre-, and while- reading stages. Hence, post-reading activity is a stage where the readers should summarise major ideas and evaluate their readings, as the validation if the readers have a deeper understanding of the text (Blachowicz \& Ogle, 2001). Therefore, this stage involves deep-level processing strategies that transform the literal meaning of the texts (Nordin et al., 2012). Some strategies during this stage are finding the main idea of the text, making inferences, taking conclusions, and reflecting upon the reading process (Ozek \& Civilek, 2006).

Some studies have discussed the learning strategies used in English reading in various countries (Temur \& Bahar, 2011) in Turkey; Lai, Tung, \& Luo, 2018 in Taiwan; Li, 2010 in China; Maghsudi \& Talebi, 2009 in India; Zare, 2010 in Iran). A study by Lai, Tung, and Luo in 2008 indicated that instructional strategies could increase the students' comprehension. Maghsudi and Talebi (2009) revealed that there were significant differences between mono/bilingual, where bilinguals had higher scores than monolinguals, but no differences in cognitive strategies for reading. This research also informed that there was no significant difference in metacognitive, cognitive and total metacognitive/cognitive strategies for English reading. The most frequently strategy used in English reading in China was problem solving and the least frequently used was support-reading strategies (Li, 2010). Zare (2010) revealed that metacognitive strategies were more frequently used in English reading followed by compensation strategies, cognitive, social, memory and the lowest frequently used was affective strategies. While Temur and Bahar (2011) revealed that the students in their research used problem solving as the most frequently strategy followed by global strategies and supporting strategies.

\section{Methodology}

The researchers used a quantitative design with a survey approach to investigate the learning strategies, which were 
used in English reading. Creswell (2012, p. 376) defines, "Survey research designs are procedures in quantitative research in which investigators administer a survey to a sample or to the entire population of people to describe the attitudes, opinions, behaviors, or characteristics of the population.”

The site of this research was one Indonesian university with 22.934 within 14 faculties. The sample of this study was all language student teachers who studied in one Indonesian university. Sample is stated as the group of individuals whom the researcher actually examined in which it is a subset of the population that is representative of the whole population (Dornyei, 2011). We addressed the survey to all Indonesian language education program students, 653 student teachers; however, only 570 responses were measurable and analyzed. To get the access for conducting this investigation, we asked for permission from the dean of the program.

The questionnaire consisted of the statements about reading strategies such as metacognitive (MC) and cognitive (C) strategies adapted from previous studies (Baker \& Boonkit, 2004; Oxford, 2003; Sheorey \& Mokhtari, 2001). A 5-point Likert scale was applied form Strongly Agree (5) to Strongly Disagree (1). The questionnaire contained close-ended questions where Johnson and Christensen (2008, p.176) say, "Closedended questions requires the respondent to decide a limited number of responses that are predetermined by the researchers". The reasons for choosing close-ended questions because according to Dornyei $(2003$, p. 33) that says, "The major advantage of closed-ended questions is that their coding and tabulation is straightforward and leaves no room for rater subjectivity." Then close-ended questions do not require participants to do any free writing that may out of the researcher aims, they only ask to choose one of the alternatives. Demographic information form was preceded the questionnaire. As many as 22 items were distributed for strategies in English reading; five items were addressed regarding pre-reading activities, fourteen items were for while-reading activities, and three items were for post-reading activities (see Table 1).

Table 1. Questionnaire items

\begin{tabular}{|c|c|c|}
\hline Stages & Items & Sample statement \\
\hline $\begin{array}{c}\text { Demographic } \\
\text { information }\end{array}$ & Q1-Q3 & How old are you? \\
\hline $\begin{array}{c}\text { Pre-reading } \\
\text { Activity }\end{array}$ & Q4-Q8 & $\begin{array}{c}\text { I preview the text before } \\
\text { reading }\end{array}$ \\
\hline $\begin{array}{c}\text { While-reading } \\
\text { Activity }\end{array}$ & Q9-Q22 & $\begin{array}{c}\text { I pay attention to the parts of } \\
\text { sentences such as phrases, } \\
\text { clauses, subjects, and objects }\end{array}$ \\
\hline $\begin{array}{c}\text { Post-reading } \\
\text { Activity }\end{array}$ & Q23-Q25 & $\begin{array}{c}\text { I make inferences after } \\
\text { finishing reading the passage }\end{array}$ \\
\hline
\end{tabular}

Content validity was carried out involving 7 experts; 3 English literacy experts and 4 English reading experts in three sessions of discussion to polarize the items of the questionnaires. The questionnaire was piloted before being distributed with Cronbach alpha of 0.9 (accepted) as stated by Pallant (2001) and Fink (2003). On the real questionnaire distribution, the participants were given from 15 to 20 minutes to answer the questionnaires. Descriptive statistics was used in analyzing the demographic background and questionnaire data which according to Dornyei (2003), it is a way that use to calculate of the numerical data that can save time and space to be more efficient. The analysis of the data aimed at revealing common strategies of English reading used by Indonesian language student teachers and reading strategy difference used by female and male students.

\section{Findings}

\subsection{Strategies of English Reading Used by Indonesian Language Student Teachers}

The findings of the common strategies in pre-reading activity were based on the highest percentage of participants' answer. The highest percentage was "I use prior knowledge to understand the text" which is a cognitive strategy with the percentage of agreement of $74,74 \%$ of 570 student teachers. It was followed by "I read the topic or heading of the passage" (MC) where $69,47 \%$ of the 570 participants agreed with this strategy. Afterward, the statement "I read the first sentence of the paragraphs first" (MC) with $68.42 \%$ of the 570 participants' agreement. "I preview the text before reading" (MC) gained $65.26 \%$ of the survey participants' agreement. Meanwhile, the least agreed statement $(63.16 \%)$ was "I look at the pictures, graphs, maps, diagrams, etc., of the passage."

For while-reading activity, the highest percentage was "I re-read for better understanding" (C) where $70.53 \%$ of the participants of the survey agreed on this strategy statement. It was followed by "I predict or guess the text meaning" (MC) agreed by $69.47 \%$ participants. "I link information in one sentence with information from the preceding ones" (MC) was next statement gained agreement percentage of $68.16 \%$. "I visualize information read" (C) with $67.21 \%$, "I predict or guess the text meaning" (MC) with $67.10 \%$. The next strategy was "I try to figure out the main idea of each paragraph" (MC) for $64,21 \%$ which was followed by $63.16 \%$ that showed by two strategies they were "I continue reading even if I have difficulties" (MC); and "I interpret the text (make inferences, draw conclusions, etc.)" (MC) with $63.16 \%$ and $63.10 \%$. For the statement, "If I don't understand something such as a word or phrase, I guess its meaning using clues from the text such as a noun, verb, adjective, adverb, etc., surrounding words, verb tense, singular and plural, word elements that is affixes and roots, synonyms and antonyms" (MC) gained $61.05 \%$ of the participants' 
agreement. "I guess the meaning of unknown words" (C) for $60.00 \%$ and "I read the whole passage quickly to understand the main idea" (MC) for 57, 89\%. While the two least chosen strategies were "I take notes, highlight or underline the important notes while I am reading the passage" (C) agreed by $53.68 \%$ of the participants and "I guess what is coming in the next sentences or paragraphs" (MC) agreed by $52.63 \%$ of the participants.

For post-reading activity, the highest percentage, $76.84 \%$, was for cognitive (C) strategy, "I check or evaluate my comprehension" which was followed by "I go back to read the details of the passage to find the answers of the questions" (C) for the agreement of $75.79 \%$ of the participants. The least percentage was agreed by $67.37 \%$ of the participants "I make inferences after finishing reading the passage" $(\mathrm{C})$.

\subsection{Reading Strategy Difference Used by Female and Male Participants}

The highest percentage of females' strategy in pre-reading activity was "I use prior knowledge to understand the text" (C) that $75,34 \%$ of female participants agreed on this strategy. Then followed by metacognitive strategy "I read the topic or heading of the passage" with $69.86 \%$ of the participants' agreement. It was followed by "I look at the pictures, graphs, maps, dia-grams, etc., of the passage" (MC) and "I read the first sentence of the paragraphs first" (MC) with $65.75 \%$ and $65.74 \%$ of participants' agreement. And the least percentage was for the strategy, "I read the topic or heading of the passage" (MC) which was supported by $69.86 \%$ of participants. Meanwhile, the highest percentage of male students for strategy used in pre-reading activity was "I read the first sentence of the paragraphs first" (MC) which was supported by $77,27 \%$ of male participants. Statement, "I use prior knowledge to understand the text" (C) was agreed by $72,73 \%$ of the participants. It was followed by "I preview the text before reading" (MC) and "I read the topic or heading of the passage" (MC) with a similar percentage of agreement of $68.18 \%$. The lowest percentage, $54.55 \%$, was "I look at the pictures, graphs, maps, dia-grams, etc., of the passage" (MC).

For while-reading activity, the highest percentage of reading strategy used by female student teachers $(69.86 \%)$ was "I re-read for better understanding" (C). Statement, "I try to figure out the main idea of each paragraph" (MC) and "I visualize information read" (C) obtained a similar percentage of $68.49 \%$ of the participants' agreement. Then, $65.75 \%$ was for "I link information in one sentence with information from the preceding ones" (MC) and "I predict or guess the text meaning" (MC). "I interpret the text (make inferences, draw conclusions, etc)" (MC) obtained the percentage of $64,35 \%$.

The female participant's percentage for the next strategies was $61,64 \%$ of participants' agreement for "If I don't understand something such as a word or phrase, I guess its meaning using clues from the text such as a noun, verb, adjective, adverb, etc., surrounding words, verb tense, singular and plural, word elements such as affixes and roots, synonyms and antonyms" (MC) and "I guess the meaning of unknown words" (C). "I pay attention to the parts of sentences such as phrases, clauses, subjects, and objects" (C) and "I confirm predictions" (MC) obtained a similar percentage of $60.27 \%$.

Finally, the lowest percentage strategies which obtained $58.90 \%$ of participants' agreement were "I read the whole passage quickly to understand the main idea" (MC) and "I continue reading even if I have difficulties" (MC). Meanwhile, the highest percentage of strategy used by male students was "I predict or guess the text meaning" (MC) with $81.82 \%$ of participants' agreement, followed by "I continue reading even if I have difficulties" (MC), $77.27 \%$. Next strategy was "I re-read for better understanding" (C) with $72.73 \%$ of participants' agreement. Furthermore, $68,18 \%$ of the participants chose "I link information in one sentence with information from the preceding ones" (MC) as the next strategies and followed by "I guess what is coming in the next sentences or paragraphs" (MC), 63.64\% of participants' agreement. It was followed by the strategies "If I don't understand something such as a word or phrase, I guess its meaning using clues from the text such as a noun, verb, adjective, adverb, etc., surrounding words, verb tense, singular and plural, word elements that is affixes and roots, synonyms and antonyms" (MC), "I visualize information read" (C), "I take notes, highlight or underline the important notes while I am reading the passage" (C), and "I interpret the text (make inferences, draw conclusions, etc.)" (MC) that showed the percentage $59.09 \%$ of the participants' agreement. "I read the whole passage quickly to understand the main idea" (MC) and "I guess the meaning of unknown words" (C) with $54.55 \%$ of participants' agreement. Then, $50.00 \%$ of participants' agreement agreed for "I try to figure out the main idea of each paragraph" (MC) in "Agree" scale. The lowest percentage was "I pay attention to the parts of sentences such as phrases, clauses, subjects, and objects" (C) with $31.82 \%$ of participants' agreement.

For post-reading activity, the highest percentage for reading strategy was "I check or evaluate my comprehension" (C) as $78.08 \%$ participants agreed with the statement and followed by "I go back to read the details of the passage to find the answers of the questions" (C) with $75.34 \%$ of participants' agreement. The lowest percentage for the strategy was "I make inferences after finishing reading the passage" (C) with $71.23 \%$ of participants' agreement. Meanwhile, for the male participants, the highest percentage for strategies in post-reading was "I go back to read the details of the passage to find the answers of the questions" (C) with $77.27 \%$ of participants' agreement. Next, 72, 73\% of participants chose "I check or evaluate my comprehension" (C). The lowest percentage of participants' choice was "I 
make inferences after finishing reading the passage" (C).

\section{Discussion}

The reading activity in this study is categorized into three stages: pre-reading, while-reading and post-reading (Nordin, et al., 2012). In these stages, the readers are suggested to use learning strategies (O'Malley et al., 1985; Oxford, 2003; Rubin, 1987). This study focused on two strategies; metacognitive and cognitive (Oxford, 2003; Rubin, 1987). The findings of this study revealed that in the pre-reading activity, the participants planned the strategies used to comprehend the reading text. The strategies that they used in this stage were strategies related to activate their background knowledge and understanding what the text is mainly about such as guessing the content of text based on the title or guessing the text about with pictures or illustration (Ozek \& Civilek, 2006). Moreover, metacognitive and cognitive strategies were used in this study by participants. Metacognitive strategies are delivered as the strategies that function to monitor or regulate the cognitive strategies which include thinking about the learning process, planning for learning, monitoring comprehension or production while it takes place, and self-evaluation of learning after the language activity was completed (Genc, 2011). Meanwhile, cognitive strategies refer to steps or operations used in learning or problem-solving, which require direct analysis, transformation, or combination of learning materials.

In the while reading activity, the findings of this study indicated that participants used cognitive strategy where their prior knowledge was useful for them to get information from the text. The findings are in line with the research conducted by Ozek and Civelek (2006) and Anderson (1991) who informed that cognitive strategies refer to steps or operations used in learning or problem-solving, which require direct analysis, transformation, or combination of learning materials. The findings of this study revealed that the participants checked or evaluated their comprehension in the post-stage to get depth understanding about the text. This strategy belongs to cognitive strategies; it means in this stage the participants prefer to do direct ways in processing the meaning of the texts. The findings are in line with previous related studies such as Nordin et al. (2012) where a conclusion needs to be taken for the text understanding. The strategies include classifying words according to their meanings and their grammatical category, summarizing the main ideas, re-reading a text to make sure in comprehending of the text and re-reading the text to remember the important information. The participants of this study intended to check or evaluate their comprehension in the post-stage to get depth understanding about the text.

The differences of reading strategies used in reading activity between male and female student teachers in pre-, while- and post- reading activities are also discussed in this study. Female student teachers were cognitive strategy users in pre-reading. It was proven by the highest percentage for each strategy categorized as a cognitive strategy. Meanwhile, male participants were metacognitive strategy users for pre-reading activity. For while-reading activity, female students were categorized as cognitive strategy users. The finding was in line with the research conducted by Ozek and Civelek (2006) and Sahan (2012) where in their study females used cognitive reading strategies in English reading. On the other hand, male student teachers were metacognitive strategy users which are not in line with what Sahan (2012) found in his study where even male student teachers used cognitive strategies in their English reading.

For post reading activity, female students were categorized as the cognitive users. In summarizing reading texts, female participants often checked and evaluated their comprehension about the texts. In contrast, male participants were cognitive strategy users; they would go back in reading the texts when they found the questions to get the answer or to comprehend the text. The finding compromises the result of the research conducted by Sahan (2012) about cognitive reading comprehension strategies employed by ELT students, where the result revealed the most frequently strategy used by students was "rereading certain points thoroughly to find evidence". Also, $\operatorname{Li}(2010)$ found male students used a bit more frequently in guessing what the material was about.

\section{Conclusions}

The aim of this study was to reveal common strategies of English reading used by Indonesian language student teachers and reading strategies difference used by female and male student teachers. Based on the findings and discussion, it is concluded that the language student teachers in this study were categorized to active reading strategy users. It was proven by the highest number percentage of participants answer in using strategies for each stage in reading activity (pre-, while- and post). Overall, based on the percentage of strategy that used by participants for each stage, it is summarized that the participants were mainly categorized as cognitive strategy users. Furthermore, the differences of female and male students in reading strategy were that female student teachers were more active in using reading strategies than that of male student teachers.

Based on the finding of the research, it is suggested that students of higher education to be more aware of the strategies that are appropriate to be used in English reading to help them comprehend English texts as well as to gather the information about the text. Finally, this research is useful for further researchers to investigate similar topics in different countries and conditions. 


\section{Appendix 1. The Questionnaire Items}

\begin{tabular}{|c|c|}
\hline Stages: & The strategies that I prefer to choose in pre-reading activity \\
\hline \multirow{5}{*}{ Pre-reading Activity } & I preview the text before reading.(MC) \\
\hline & I use prior knowledge to understand the text. (C) \\
\hline & I read the topic or heading of the passage. (MC) \\
\hline & I look at the pictures, graphs, maps, dia-grams,etc., of the passage. (MC) \\
\hline & I read the first sentence of the paragraphs first.(MC) \\
\hline Stages: & The strategies that I prefer to choose in while-reading activity \\
\hline \multirow{14}{*}{ While-reading Activity } & I pay attention to the parts of sentences such as phrases, clauses, subjects, and objects. (C) \\
\hline & I link information in one sentence with information from the preceding ones.(MC) \\
\hline & I read the whole passage quickly to understand the main idea. (MC) \\
\hline & I try to figure out the main idea of each paragraph.(MC) \\
\hline & I continue reading even if I have difficulties. (MC) \\
\hline & $\begin{array}{l}\text { If I don't understand something such as a word orphrase, I guess its meaning using cluesfrom the text such as a noun, } \\
\text { verb, adjective, adverb, etc.,surrounding words, verb tense, singular and plural, word elements that is affixes and } \\
\text { roots, synonyms and antonyms. (MC) }\end{array}$ \\
\hline & I visualize information read. (C) \\
\hline & I re-read for better understanding. (C) \\
\hline & I guess the meaning of unknown words. (C) \\
\hline & I guess what is coming in the next sentences or paragraphs. (MC) \\
\hline & I take notes, highlight or underline the important notes while I am reading the passage.(C) \\
\hline & I predict or guess the text meaning. (MC) \\
\hline & I confirm predictions. (MC) \\
\hline & I interpret the text (make inferences, draw conclusions, etc). (MC) \\
\hline Stages: & The strategies that I prefer to choose in post-reading activity \\
\hline \multirow{3}{*}{ Post-reading Activity } & I make inferences after finishing reading the passage. (C) \\
\hline & I check or evaluate my comprehension.(C) \\
\hline & I go back to read the details of the passage to findthe answers of the questions. (C) \\
\hline
\end{tabular}

\section{REFERENCES}

[1] Abrar, M., Mukminin, A., Habibi, A., Asyrafi, F., Makmur, M., \& Marzulina, M. (2018). "If our Englis isn't a language, what is it? Indonesian EFL student teachers' challenges speaking English. The Qualitative Report, 23(1), 129-145

[2] Alfassi, M. (2004). Reading to learn: Effects of combined strategy instruction on high school students. The journal of educational research, 97(4), 171-185.

[3] Baker, W., \& Boonkit, K. (2004). Learning strategies in reading and writing: EAP contexts. RELC Jo urnal, 35(3), 299-328.

[4] Bezci, E. Ö. (1998). An investigation of the cognitive reading strategy needs of the freshman students at Hacettepe University (Doctoral dissertation, Bilkent University).

[5] Bidabadi, F. S. \& Yamat, H. (2011). The relationship between listening strategies used by Iranian EFL freshman university students and their listening proficiency levels.
English language teaching. 4 (1). 26-32.

[6] Brown, D. (2007). Principles of language learning (5th edition). New York: Pearson Longman.

[7] Creswell, J.W. (2012). Educational research: Planning, conducting and evaluating quantitative and qualitative research. Boston: Pearson Education, Inc.

[8] Blachowicz, C., \& Ogle, D. (2001). Learning about comprehension from good readers.

[9] Dornyei, Z. (2003). Questionnaires in second language research. London: Lawrence Erlbaum Associates, Inc.

[10] Dornyei, Z. (2011). Research methods in applied linguistics. Oxford: Oxford University Press.

[11] Fink, A. (2003). The survey handbook (2 ${ }^{\text {nd }}$ edition). California: Sage publication, Inc.

[12] Genc, H. (2011). Paper and screen: Reading strategies used by low-proficient EFL learners. Sino-US English Teaching, 8 (10). 648-658.

[13] Hardan. (2013). Language learning strategies: A general overview. Social \& behavioural sciences. 12(194). 
[14] Hermida, J. (2009). The importance of teaching academic reading skills in first-year university courses. The International Journal of Research and Review, 3. 20-30.

[15] Husarida, H., \& Dollete, R. (2019). Perceived Effectiveness on the Use of English Language in Teaching Mathematics and Science. Indonesian Research Journal in Education |IRJE|, 3(1), 177-198. https://doi.org/10.22437/irje.v3i1.69 61

[16] Johnson, B., \& Christensen, L. (2008). Educational research: Quantitative, qualitative, and mixed approaches. Sage.

[17] Keshavarz, M. H., \& Ghamoushi, M. (2014). A comparative study of metacognitive awareness of reading strategies among monolingual and bilingual Iranian EFL learners. Australian International Academic Centre, Australia, 5 (4). 25-32.

[18] Khajavi, Y., \& Ketabi, S. (2012). Influencing EFL learners' reading comprehension and self-efficacy beliefs: The effect of concept mapping strategy. Porta Linguarum, 17. 9-27.

[19] Khoshsima, H., \& Tiyar, R. F. (2014). The effect of summarizing strategy on reading comprehension of Iranian intermediate EFL learners. International Journal of Language and Linguistics, 2 (3). 134-139.

[20] Lai, L. Y., Tung, J. Y., \& Luo, Y. S. (2008). Theory of reading strategies and its application by EFL learners: Reflections on two case studies. 153-168.

[21] Lavraskas, P. J. (2008). Survey research method. USA: SAGE Publications, Inc.

[22] Li, F. (2010). A study of English reading strategies used by senior middle school students. Asian Sosial Science, 6 (10). 184-192.

[23] Li, J., \& Chun, K-W. C. (2012). Effects of learning strategies on student reading literacy performance. The Reading Matrix, 12 (1). 30-38.

[24] Maghsudi, M., \& Talebi, H. S. (2009). The impact of lingualuity on the cognitive and metacognitive reading strategies awareness and reading comprehension ability. $J$ Soc Sci, 18 (2). 119-126.

[25] Mahdavi, M., \& Mehrabi, M. (2014). Metacognitive awareness of reading strategies among Iranian EFL learners in an "input-poor" environment. International Journal of Innovation and Applied Studies, 5(4). 360-366.

[26] Mahmoudi, E. (2014). Reading strategy use among Iranian EFL learners. International Journal of Language Learning and Applied Linguistics World, 6 (1). 371-378.

[27] Makmur., Mukminin, A., Ismiyati, Y., \& Verawati. (2016). In search of good student teachers in writing skill: the impact of different task variance of EFL writing proficiency. International journal of academic research in education, 2(1).

[28] Marzulina, L., Nova, L. P., Herizal., Holandyah, M., Erlina, D., \& Lestari, I. T. (2018). Looking at the link between parents' educational backgrounds and students' English achievement. Indonesian Research Journal in Education |IRJE|, 3(1), 57-76. https://doi.org/10.22437/irje.v3i1.6507

[29] Mihara, K. (2011). Effects of pre-reading strategies on
EFL/ESL reading comprehension. Tesl Canada Journal/Revue TESL Du Canada, 28 (2). 51-73.

[30] Mukminin, A., Haryanto, E., Sutarno., Sari, S, R., Marzulina, L., Hadiyanto., \& Habibi, A. (2018). Bilingual education policy and Indonesian students' learning strategies. İlkögrretim Online, 17(3), 1204-1223.

[31] Mukminin, A., Masbirorotni, M., Noprival, N., Sutarno, S., Arif, N., \& Maimunah, M. (2015). EFL speaking anxiety among senior high school students and policy recommendations. Journal of Education and Learning, 9(3), 217-225.

[32] Munsakorn, N. (2012). Awareness of reading strategies among EFL learners at Bangkok university. World Academy of Science, Engineering and Technology, 5. 253-256.

[33] Naidu, B., Briewin, M., \& Embi, A. M. (2013). EFL learners' choice of reading strategies in a reading classroom. European Journal of Educational Studies, 5(1). 57-62.

[34] Noli, M. N., \& Sabariah, M. R. (2011). Reading strategies of English as a second language (ESL) high and low achievers. English Language Journal, 4, 49-66.

[35] Nordin, M. N., Rashid, M. S., Zubir, S. S. I. S., \& Sadjirin, R. (2012). Differences in reading strategies: How ESL learners really read. Procedia - Social and Behavioral Sciences, 90. 468-477.

[36] OECD. (2015). Pisa 2015 result in focus. Retrieved from http://www.oecd.org:

http://www.oecd.org/pisa/pisa-2015-results-in-focus.pdf

[37] O'Malley, J. M., Chamot, A. U., Stewner - Manzanares, G., Kupper, L., \& Russo, R. P. (1985). Learning strategies used by beginning and intermediate ESL students. Language learning, 35(1), 21-46.

[38] Oxford, R. L. (2003). Language learning styles and strategies: An overview. Gala.

[39] Oxford, R. L. (1989). Use of language learning strategies: A synthesis of studies with implications for strategy training. System, 17(2), 235-247.

[40] Ozek, Y., \& Civelek, M. (2006). A study on the use of cognitive reading strategies by ELT students. The Asian EFL Journal. 1-26.

[41] Pallant, J. (2001). A Step by Step Guide to Data Analysis Using SPSS for Windows (version 12), Open University Press, Buckingham, Philadelphia.

[42] Poole, A. (2009). The reading strategies used by male and female Colombian university students. Profile 11. 29-40.

[43] Sahan, A. (2012). Cognitive reading comprehension strategies employed by ELT students. 1-22.

[44] Salataci, R. (2002). Possible effects of strategy instruction on L1 and L2 reading. Reading in a foreign language, 14(1), 1.

[45] Saricoban, A. (2002). Reading strategies of successful readers through the three phase approach. The Reading Matrix, 2(3).

[46] Shang, F. H. (2011). Exploring the relationship between 
EFL proficiency level and reading strategy use. Centre for Promoting Ideas, USA. 18-27.

[47] Shen, Y. M. (2013). Toward an understanding of technical university EFL learners' academic reading difficulties, strategies, and needs. Electronic Journal of Foreign Language Teaching, 10 (1). 70-79.

[48] Sheorey, R., \& Mokhtari, K. (2001). Differences in the metacognitive awareness of reading strategies among native and non-native readers. System, 29(4), 431-449.

[49] Temur, T., \& Bahar, O. (2011). Metacognitive awareness of reading strategies of Turkish learners who learn English as a foreign language. European Journal of Education Studies, 3 (2). 421-427.

[50] Tsai, C. C. (2008). English reading comprehension strategies employed by two elderly EFL readers. Journal of Nan Kai, 5 (2). 7-12.

[51] Vianty, M. (2007). The comparison of students' use of metacognitive reading strategies between reading in Bahasa Indonesia and in English. International Education Journal, 8 (12). 449-460.

[52] Zare, P. (2010). An Investigation into language learning strategy use and gender among Iranian undergraduate language learners. World Applied Journal 11(10). 1238-1247.

[53] Zare, P., \& Othman. M. (2013). The relationship between reading comprehension and reading strategy use among Malaysian ESL learners. International Journal of Humanities and Social Science, 3 (13). 187-193.

[54] Zhang, L., \& Seepho, S. (2013). Metacognitive strategy uses and academic reading achievement: Insights from a Chinese context. Electronic Journal of Foreign Language Teaching, 10 (1). 54-69. 